\title{
Governance and takeovers: are public-to-private transactions different from traditional acquisitions of listed corporations?
}

WEIR, C. and WRIGHT, M. 


\title{
Governance and Takeovers: Are Public to Private Transactions Different From Traditional Acquisitions of Listed Corporations?
}

\author{
Charlie Weir* and Mike Wright** \\ *Aberdeen Business School \\ Robert Gordon University \\ Garthdee Road \\ Aberdeen AB10 7 QE \\ Scotland \\ UK \\ **Centre for Management Buyout Research \\ Nottingham University Business School \\ University of Nottingham \\ Jubilee Campus \\ Wollaton Road \\ Nottingham NG8 1BB \\ England \\ UK
}

Acknowledgements: Thanks to David Laing for excellent research assistance. We would also like to acknowledge the helpful comments of the editor and an anonymous referee. Our thanks also to Sudi Sudarsanam and Noel O'Sullivan for comments on earlier drafts. The usual caveat applies.

Correspondence to Professor Charlie Weir

c.weir@rgu.ac.uk

Tel +44 1224263812 


\title{
Governance and Takeovers: Are Public to Private Transactions Different From Traditional Acquisitions of Listed Corporations?
}

\begin{abstract}
Using a unique hand-collected dataset comprising 96 public to private (PTP) transactions and 258 acquisitions of listed corporations by existing corporate groups completed during the period 1998 to 2000, this paper investigates the extent to which PTPs have different internal and external governance and other characteristics from traditional acquisitions of listed corporations by existing corporate groups. The paper analyses acquisition activity during a period in which three new features were present: the decline in hostile takeovers, the increase in the adoption of governance Codes of Best Practice and the growth in PTP activity. PTPs are usually a response to takeover threat, Lehn and Poulsen (1989) and so the paper analyses the acquisition decision from two perspectives: first, takeovers as a disciplinary mechanism which substitute for weak internal governance and second, as part of a non-disciplinary framework where takeovers are complementary to internal governance mechanisms. We find support for the argument that improved internal governance and non-disciplinary takeovers, that is takeovers where the motive is not as a response to under-performing management, are complementary. PTPs are more likely to have higher board ownership and are likely to have duality of CEO and Chair. They are also more likely to have lower growth prospects and lower valuations. However, they do not have suboptimal internal corporate governance structures in terms of lower proportions of outside directors. With respect to external governance, they are not more likely to experience pressure from the market for corporate control in the form of greater takeover speculation and are also not more likely to suffer hostile threats. We find that PTPs involving management buy-outs (MBOs) have fewer non-executive directors and a greater incidence of duality. MBOs also have higher board shareholdings. We find no evidence that Management Buy-ins (MBIs) have different characteristics. Our results suggest that going private by $\mathrm{MBO}$ may result from management having private information that leads them to believe that the market has an incorrect perspective of the company's prospects.
\end{abstract}




\section{Governance and Takeovers: Are Public to Private Transactions Different From Traditional Acquisitions of Listed Corporations?}

\section{Introduction}

Corporate governance involves external and internal mechanisms. External mechanisms essentially concern the market for corporate control in which, in theory, underperforming management are disciplined and replaced following a successful hostile takeover bid. Internal governance mechanisms relate to the panoply of incentive and control mechanisms associated with board share ownership, board composition and external blockholdings of shares.

Important changes have occurred with respect to external and internal governance in the UK during the 1990s. First, there has been a decline in hostile takeover activity from a quarter of all acquisitions of UK listed companies in the mid-1980s (Franks and Mayer, 1996) to only $6.1 \%$ by the late 1990s (Weir and Laing, 2003), with a corresponding increase in friendly takeovers. ${ }^{1}$ Second, there has been increased focus on the development of new 'best practice' codes for enhancing internal corporate governance through, for example the strengthening of corporate boards (Cadbury, 1992; Hampel, 1998, Combined Code of Best Practice 1998). These codes have particularly focused on enhancing managerial accountability (Short, et al., 1999). Third, the period saw a significant increase in the number and value of public to private transactions (PTPs). Over the period 1991-1997, 4.8\% of acquisitions involving publicly quoted companies were PTPs. During 1998-2000, the figure rose to $23.7 \%$ with the figure increasing in each of these years. In addition, the value of assets

\footnotetext{
${ }^{1}$ Even this split, however, may not accurately reflect the true situation. For example, Schwert (2000) argues that any initial rejection of an approach may simply indicate an attempt to get the bidder to enter into an auction process the purpose of which is to increase the value of the bid. In addition, Boone and Mulherin (2002) argue that the traditional definition ignores potential private auctions.
} 
taken private increased from $£ 2,524$ million in 1998 to $£ 9,363$ million in 2000

(CMBOR, 2003). The paper analyses these three trends.

While O'Sullivan and Wong (1999) consider the substitution of different governance mechanisms and find significant differences in internal governance between hostile takeovers $^{2}$ and firms that remain listed, the first two trends above raise important questions about the relationship between external and internal governance (Short, et al., 1999; Dedman, 2003). In particular, they suggest that this relationship may have changed to one in which the market for corporate control and internal governance mechanisms are complements rather than substitutes. Improved internal governance may reduce the need for external governance, while the increase in friendly takeovers may reflect other non-disciplinary motives for acquisition. Disciplinary takeovers are those that occur in response to under-performance by management (Manne, 1965; O'Sullivan and Wong, 2005), while in non-disciplinary takeovers this is not the case.

In a PTP, the publicly owned equity of a company is acquired and the new company is taken private, creating a new independent entity, typically with enhanced governance and incentive mechanisms involving close monitoring by debt holders, private equity firms and significant equity stakes for executives. These mechanisms emphasise both accountability and the taking of entrepreneurial decisions by managers. In some of these firms, incumbent management may take significant equity stakes, creating a management buy-out (MBO), whilst in others equity may be largely held by new

\footnotetext{
${ }^{2}$ The analysis of publicly quoted firms that have been acquired tends to be undertaken from one of the following methodologies. First, the comparison of all characteristics of acquired firms with those of non-acquired firms (e.g. Palepu 1986). Second, the comparison of firms acquired in hostile and nonhostile take-overs (e.g. Martin and McConnell 1991; Franks and Mayer 1996; Kennedy and Limmack 1996). Third, a comparison of the characteristics of firms acquired by friendly take-over with those of non-acquired firms (e.g. Song and Walkling 1993; Nuttall 1999). Fourth, a comparison of firms involved in hostile acquisitions with those of non-acquired firms (e.g. Shivdasani 1993).
} 
incoming management and the private equity financier, creating a management buy-in (MBI). MBOs and MBIs potentially raise different issues concerning access to information and governance.

The emergence of PTPs extends not only traditional perspectives on the market for corporate control but also the nature of internal governance. On the one hand, firms subject to PTPs may have inferior internal governance mechanisms prior to going private. Private equity firms with specialist monitoring expertise and contractual mechanisms represent a new external governance mechanism that involves taking these firms private and improving their internal governance. Alternatively, the development of corporate governance codes may lead to at least a prima facie convergence of internal governance mechanisms across firms. In these cases, PTPs may be more likely to occur where internal governance mechanisms focused on accountability in the context of stock market regulation constrain management's ability to undertake entrepreneurial decisions (Short et al., 1999).

The objective of this paper is to investigate the changes that occurred in the market for corporate control during the late 1990s. It will evaluate the extent to which firms going private have different external and internal governance and monitoring characteristics from traditional acquisitions of listed corporations by existing corporate groups. As such, the paper aims to make the following contributions to the literature. First, it presents an analysis of acquisition activity during a period in which three new features have been present - the decline in hostile takeovers, the increase in the adoption of governance Codes of Best Practice and the growth in PTP activity. It therefore analyses the acquisition decision from two perspectives: takeovers as a 
disciplinary mechanism and as part of a non-disciplinary framework. The disciplinary perspective represents the traditional role of the market for corporate control in which poorly performing companies are bought and ineffective management is replaced. This context was used by, for example, Lehn and Poulsen (1989) to explain PTP activity. Given the decline in hostile, disciplinary acquisitions, the non-disciplinary approach attempts to analyse the market as it now appears to be operating. Separating acquired firms into PTPs and traditional acquisitions of listed corporations provides valuable additional insights into developments in the external monitoring process. Within this context we analyse the role of board ownership as an influence on the decision to go private. Second, our focus extends both previous work on PTPs that has examined the growth prospects, free cash flow and market for corporate control hypotheses relating to the acquisition of firms (Jensen, 1986), and previous work on internal governance in takeovers (O’Sullivan and Wong, 1999). It does this by incorporating the impact of internal governance mechanisms and the role of ownership structure on the decision to go private. Third, we analyse how far public to private buy-outs can be viewed as a homogeneous group by comparing incumbent-led buy-outs (MBOs) with those led by outsiders (MBIs).

Our findings show that PTPs and traditional acquisitions of listed corporations differ in terms of certain aspects of external and internal governance and monitoring mechanisms. In terms of internal governance mechanism, there is no evidence of differences in terms of non-executive directors although there is more likely to be duality of CEO and Chair. There is also no evidence that they had more free cash flow but their growth prospects were lower. Therefore, with respect to the traditional disciplinary role of hostile takeovers, we find limited evidence that PTPs were more 
likely to suffer from agency costs but they did not experience a greater threat of hostile takeover. However, we do find that public-to-private acquisitions had higher board shareholdings than traditional acquisitions of listed corporations, which is further support for the view that recent PTPs cannot be explained in terms of a reaction to the threat of disciplinary takeover brought about by high agency costs.

We find support for the hypothesis that we can differentiate between PTPs and traditional acquisitions of listed corporations within a non-disciplinary framework. We find that some firms going private have lower valuations, indicating managerial private information, and greater board ownership suggesting that outside bidders have been deterred from bidding for the firms because of the potential difficulties involved in dealing with significant board ownership.

The issue of board ownership is investigated further by comparing high board ownership PTPs and low board ownership PTPs with traditional acquisitions of listed corporations. High board ownership PTPs have higher free cash flows and lower growth prospects. In addition, they have fewer non-executive directors and more duality. However, they also have higher internal ownership and do not face greater pressure from outside bidders than traditional acquisitions of listed corporations. This suggests that board ownership and board structure are substitute governance mechanisms. It is also consistent with the fact that, although there is greater awareness about board mechanisms, shareholders may be willing to accept a board structure that appears non-optimal. However, high board ownership PTPs do have an average of two independent non-executive directors, which is consistent with the 1998 Combined Code of Best Practice prevailing at the time of the study. They also have an average of 
$36 \%$ non-executive directors, which is above the figure quoted in the Combined Code. This suggests that PTPs do not suffer non-desirable non-executive director representation. In addition, Hampel (1998) recognises that duality may be appropriate for smaller firms, something which is true for high board ownership PTPs.

Our findings also show that PTPs that are MBOs have a higher incidence of duality and fewer non-executive directors. However, the percentage of non-executive directors is in line with the 1998 Combined Code of Best Practice. MBOs also have higher board ownership. Therefore, going private implies that the management has private information about the prospects of the firm, which is not reflected in the stock market's view of the company. Overall, our findings emphasise the importance of a non-disciplinary explanation for PTPs relative to traditional acquisitions of listed corporations.

The paper is structured as follows. In the next section the literature relating to acquisitions and PTPs is discussed. Then the data and research design are outlined in section 3. The results are then discussed in section 4 and the analysis development in section 5. Finally, some conclusions are drawn in section 6.

\section{Previous literature and hypothesis development}

A number of differences between public to private (PTP) takeovers and other acquisitions of listed corporations have important internal governance implications. First, a PTP means that the company will have been taken out of public control and will no longer be quoted on the stock market. Therefore, the company will cease to be subject to public monitoring and hence will not incur the bonding and monitoring 
costs associated with being publicly quoted. In contrast, a publicly listed corporation acquired by another publicly listed corporation is still to some degree, even if it is indirectly, subject to the effects of public monitoring through analysts' scrutiny of its parent. Second, public-to-private transactions tend to involve private equity firms who typically take significant equity stakes and board representation (CMBOR, 2003). ${ }^{3}$ Third, the funding structure following the PTP usually involves a higher proportion of debt (CMBOR, 2003). In contrast, acquisition by another public company may be more likely to see the continuation of a relatively low proportion of debt in the funding structure, even where the acquisition is funded by increased borrowings by the bidder (Sudarsanam and Mahate, 2003). ${ }^{4}$ This implies increased monitoring postgoing private.

In this section, we first consider the substitution arguments regarding differences in traditional disciplinary hostile takeover activity between PTPs and traditional acquisitions of listed corporations. We consider the differences between PTPs and traditional acquisitions of listed corporations in terms of the traditional arguments for going private, that is weak governance associated with agency problems, excess free cash flows, poor growth prospects, low board shareholdings and the threat of hostile takeover. Second, we consider the complementarity arguments with respect to the growing awareness of internal governance mechanisms during a period of a decline in hostile acquisitions and a rise in non-disciplinary takeovers. We evaluate the differences between PTPs and traditional acquisitions of listed corporations in relation

\footnotetext{
${ }^{3}$ Over the period $1998-2000,79.4 \%$ of all PTPs involved private equity firms. The figure increases as the value of the PTP increases, with private equity firms being involved in $91.9 \%$ of PTPs that were in excess of $£ 50$ million, (CMBOR, 2003).

${ }^{4}$ Sudarsanam and Mahate (2003). found that over the period 1983-1995 in the UK, $18.7 \%$ of acquisitions were financed by only cash, $19.8 \%$ by only equity and $61.5 \%$ by a mixture of the two. In contrast, over the period 1991-2000, debt provided an average of $42.4 \%$ of the funding of UK PTP transactions, (CMBOR, 2003).
} 
to a non-disciplinary environment in which management perceptions about market undervaluation and management insider knowledge are likely to play a greater part in the decision to go private.

We are not aware of any study that has attempted to differentiate between PTPs and traditional acquisitions of listed corporations in a period when non-hostile acquisitions are the rule. ${ }^{5}$ Halpern et al. (1999) compared leveraged buy-outs (LBOs) with a random sample of traditional acquisitions of listed corporations during 1981-86, a time when hostile acquisitions were much more common in the US than now. ${ }^{6}$ They found that the probability of engaging in an LBO increased as managerial share ownership increased and was higher if take-over interest had been reported in the Wall Street Journal. They found no evidence of any difference in either growth prospects or free cash flows.

\section{(i) Disciplinary takeovers and substitutability}

Hostile takeovers are traditionally viewed as a key mechanism for disciplining underperforming managers. A substantial literature examines traditional acquisitions during periods of significant hostile takeover activity. For example, O'Sullivan and Wong (1999) consider the substitution of different governance mechanisms and find significant differences in internal governance between hostile takeovers and firms that remain listed. In addition, the likelihood of significant turnover of senior management of the acquired firm following takeover (Kennedy and Limmack, 1996; Franks and

\footnotetext{
${ }^{5}$ In the US, the literature on public to private transactions tends to compare PTPs with firms that remain public, (e.g. Halpern et al., 1999; Kaplan, 1989; Lehn and Poulsen, 1989; Maupin et al., 1984; Kieschnick 1998). Alternatively it looks at the impact of PTPs on the share price, (e.g. DeAngelo et al., 1984; Frankfurter and Gunay, 199; Torabzadeh and Bertin, 1987).

${ }^{6}$ Their discussion stresses the importance of the threat of hostile take-over but does not indicate the composition of their control sample of acquired firms in terms of the proportions of hostile or nonhostile acquisitions.
} 
Mayer, 1996; Dahya and Powell, 1999; Kini et al., 2004) suggests that the threat of hostile acquisition would provide the impetus to return some of the residual claims to other shareholders. This suggests that in general, PTPs are more likely to be associated with a disciplinary hostile take-over threat than are traditional acquisitions of listed corporations.

Firms involved in PTP transactions have traditionally been argued to have characteristics associated with incentive misalignment and poor monitoring prior to the decision to go private and so will have incurred higher agency costs than traditional acquisitions of listed corporations (Jensen, 1986). Firms going private are expected to be in mature, low growth sectors with high free cash flow, with the PTP transaction enabling the return of some of the free cash flow to shareholders as a result of improved governance and incentive realignment post-buy-out. Traditional acquisitions of listed corporations are less likely to exhibit these characteristics because if they did, there would have been pressure to take the firm private. Corporate acquirers may be able to obtain synergy benefits from acquiring low growth firms but may find firms with low growth prospects are less attractive.

The US evidence regarding the extent of free cash flow in PTPs is, however, mixed. Lehn and Poulsen (1989) found that firms going private had higher free cash flows than firms that remained quoted. Other evidence suggests that free cash flow has no impact on the decision to go private (Opler and Titman, 1993; Halpern et al., 1999) and there is no evidence that other takeovers in general have high free cash flows, (Morck, et al.,1988; Powell, 1997). Similarly, the US evidence on the growth of PTPs relative to other acquisitions is again mixed, with Lehn and Poulsen (1989) supporting 
this argument while other studies using different measures find that firms going private did not have poorer growth prospects than firms remaining public (Opler and Titman, 1993; Halpern et al., 1999).

However, agency costs associated with high free cash flows and low growth prospects may induce the threat of a hostile, disciplinary takeover which substitutes for weak governance and poor incentive alignment (Jensen, 1986; Lehn and Poulsen, 1989). The first wave of PTPs in the US was subjected to more takeover speculation in the financial press than firms that remained public (Lehn and Poulsen, 1989). In addition, Halpern et al. (1999) report that firms involved in PTPs were more likely to experience takeover speculation than traditional acquisitions of listed corporations. If PTPs did exhibit the characteristics of poor growth prospects, high free cash flows, poor stock market performance and low board ownership, they would be susceptible to a disciplinary, outside bid.

The argument that going private is a response to the threat of hostile takeover also has implications for the governance structures of firms since it implies that the threat is a substitute for non-optimal boards. In the UK, the 1998 Combined Code of Best Practice $^{7}$ identified significant non-executive director representation as bringing effective monitoring to ensure that policies consistent with shareholder objectives are followed by the board. Given the Combined Code's emphasis on a meaningful nonexecutive director presence, we would expect firms going private to have fewer nonexecutive directors than firms subject to traditional acquisitions by existing listed corporations.

\footnotetext{
${ }^{7}$ The Combined Code was revised in 2003 (Combined Code, 2003). The study deals with a period in which the original 1998 Combined Code was applicable.
} 
The above discussion gives the following hypotheses in terms of distinguishing between PTPs and traditional acquisitions of listed corporations where PTPs are being driven by the incentive realignment model. Firms going private are more likely than traditional acquisitions of listed corporations to have: lower growth prospects (hypothesis H1a); higher free cash flows (hypothesis H1b); ineffective internal board governance structures (hypothesis H1c); lower board ownership hypothesis H1d); lower valuation (hypothesis H1e); greater takeover speculation (hypothesis H1f).

\section{(ii) Non-Disciplinary takeovers and complementarity}

There has been growing awareness of the impact of effective internal governance mechanisms as a result of a number of reports (Cadbury, 1992; Greenbury 1995: Hampel, 1998). The increased effectiveness of internal governance mechanisms has happened during the same period as the decline in hostile takeovers. As internal governance improves, it becomes more difficult for managers to protect their own interests by rejecting a bid, hence the reduction in hostile takeovers. In the UK, significant adoption of the recommendations made by the Combined Code (Peasnell, et al. 2003; Dahya et al. 2002) has coincided with the increase in friendly takeovers. This suggests that the market for corporate control and internal governance mechanisms are complements rather than substitutes.

In addition, Franks and Mayer (1996) and Kini et al. (2004) both argue that we can no longer view hostile takeovers as disciplinary, as for example, Morck et al. (1986), because there is no evidence that hostile targets and non-hostile targets perform differently. For example, there is evidence that friendly targets are not poor 
performers, (Morck et al. 1988; Franks and Mayer 1996; Powell 1997; Weir 1997; North 2001). Thus Franks and Mayer (1996) conclude that bid hostility is now a consequence of disagreement about the terms of the deal arising from valuation differences rather than a disciplinary mechanism. Kini et al. (2004), who study a period in the US during which the incidence of hostile takeovers was lower, argue that the traditional concept of hostility no longer applies because the disciplinary role of the market for corporate control has been replaced by anti-takeover defences and the growing importance of internal corporate governance mechanisms. The use of antitakeover mechanisms is much less common in the UK (Sudarsanam, 2003) so, in the UK context, we emphasise internal governance as a complement to the decline in hostile takeovers given that the decline happened at the same time as the improvement in internal governance mechanisms.

a) Internal governance mechanisms

In the UK, the 1998 Combined Code of Best Practice identified two key internal mechanisms for controlling managerial discretion. ${ }^{8}$ First, as noted earlier, significant non-executive director representation (Fama, 1980; Rosenstein and Wyatt, 1990; Cadbury, 1992) brings the necessary objectivity, skills and experience that enable effective monitoring to ensure that policies consistent with shareholder objectives are followed by the board. The 1998 Combined Code recommended that boards should have at least one third non-executive directors (the original 1992 Cadbury Code recommended at least three non-executive directors, a number not changed in the Combined Code). Dahya et al. (2002) show that in the post Cadbury Code of Best

\footnotetext{
${ }^{8}$ UK quoted companies have been adopting the internal governance structures recommended in the 1998 Combined Code (Peasnell, et al. 2003; Dahya et al. 2002), particularly with the appointment of additional non-executive directors and in reducing the incidence of duality. There is no legal requirement to adopt these structures but companies must include a governance statement in their accounts detailing how far they have implemented the Combined Code of Best Practice.
} 
Practice period, the resultant increase in non-executive directors appears to have made the removal of a poorly performing CEO more likely.

The second important governance mechanism identified in the Combined Code relates to duality, the situation where one person takes on the posts of both Chair and CEO. The Combined Code takes the view that, unless the company is small, duality is undesirable given the degree of control and influence that it gives to one person in the decision-making process.

The influence of duality on performance and the takeover process is not, however, simple. For example, contrary to expectations, Boyd (1995), using US data, finds that duality improved performance. Further, UK studies by Vafeas and Theodorou (1998) and Weir et al. (2002) report that it had no adverse effect on performance. In the US, Shivdasani (1993) finds that duality reduced the probability of a hostile bid. In the UK, O'Sullivan and Wong (1999) find an insignificant relationship between the presence of duality and the likelihood of becoming a hostile target. Duality may also be a signal of strong leadership (Baliga et al., 1996).

The development of corporate governance codes will lead to a convergence of internal governance mechanisms, especially where adoption is high, (Ezzamel and Watson, 2005). Thus, the predominance of non-disciplinary takeovers suggests that PTPs and traditional takeovers of listed corporations by existing corporate groups are likely to have similar board characteristics.

(b) Management undervaluation perceptions 
As noted earlier, Franks and Mayer (1996) and Kini et al. (2004) argue that the rejection of an initial hostile bid approach is now a function of the disagreement about a bid's terms arising from valuation differences. In the absence of hostile takeovers, valuation differences are not disciplinary in nature but result from management having private, inside information. There is some evidence that PTPs are undervalued relative to firms that remain public. Weir et al. (2005a) distinguish between perceived and objective undervaluation. They find, in respect of the former, that PTPs experience a decline in share price relative to firms that remain public. This suggests that the managers had some private information that led them to value the company differently to the market. If the market does not value this information, incumbent management may see listing costs as an unnecessary burden. The management of traditional acquisitions of listed corporations would not have had such a different valuation otherwise they would have set in motion a PTP. We therefore expect that PTPs will be undervalued relative to traditional acquisitions of listed corporations.

\section{(c) Insider ownership}

Board ownership is likely to be higher in firms going private than in traditional acquisitions of listed corporations. Specifically, with respect to PTPs, Halpern et al. (1999) report that firms involved in LBOs have significantly higher managerial share ownership than those involved in traditional acquisitions of listed corporations. Where founders remain in position in listed corporations, a desire for independence to realise their growth objectives may lead them to resist becoming part of a larger group. If they have retained a significant share of equity they may be able to resist pressure for takeover by another corporation. Potential acquirers may be dissuaded from purchasing such businesses because of the potential problems in integrating dominant 
founders. In contrast, these businesses may be attractive PTP candidates as the private equity firms funding them are likely to seek to support good entrepreneurial management and also have the specialist expertise and contractual mechanisms to monitor them (Sahlman, 1990; Wright and Robbie, 1998). As a result, we hypothesise in general that firms going private are expected to have higher internal shareholdings than traditional acquisitions of listed corporations.

The above discussion leads to the following hypotheses for distinguishing between PTPs and traditional acquisitions of listed corporations in a non-disciplinary framework. Compared to traditional acquisitions of listed corporations, PTPs are: not likely to have lower growth prospects (hypothesis $\mathrm{H} 2 \mathrm{a}$ ); not likely to have higher free cash flows (hypothesis H2b); not likely to exhibit poorer board governance structures (hypothesis H2c); likely to have higher board ownership (hypothesis H2d); likely to experience undervaluation (hypothesis $\mathrm{H} 2 \mathrm{e}$ ); not likely to experience more takeover speculation (hypothesis H2f).

\section{Data and research design}

\section{(i) Sample}

The sample consists of 354 UK quoted acquisitions. Of these, 96 were public to private transactions and 258 were other publicly quoted companies that were acquired during the period 1998 to 2000 . To be included, acquired companies have to have complete financial and governance data available. We exclude acquisitions of companies in the financial services sector. Firms in this sector have non-standard accounts and cannot be compared to firms in the other sectors. They are also subject to external scrutiny by the Financial Services Authority which means that the usual governance-agency issues may not apply. Over the period there were 500 acquisitions 
of UK public companies. Of these, 100 were in the financial services sector and 46 had missing or incomplete data. This gives the final sample of 354.

The PTP and acquisitions data were collected from a number of sources. First, we used data from Acquisitions Monthly, which publishes information on acquisition activity in the UK. Second, data on the public-to-private transactions were supplied by the Centre for Management Buyout Research, which is based at the University of Nottingham, and the Financial Times Intelligence Service. Financial information used to calculate sales growth, free cash flow and capital expenditure was taken from Extel Primark Company Analysis, which provides accounting and financial data on UK quoted companies. The figures used were taken from the last accounts published prior to the acquisition. Thus, if the acquisition occurred in 1998, the data refer to the accounts published in 1997. The corporate governance and shareholding data were taken from the PricewaterhouseCoopers Corporate Register (1998, 1999, 2000, and 2001) which provides information on internally held shareholdings and external shareholdings in excess of three percent. It also gives details of board structure. Ownership and board structure data also refer to the year prior to the year of takeover. Information on takeover rumours came from FT Intelligence, which provides newspaper text reports.

\section{(ii) Variable definition}

The variables used in the analysis are defined as follows -

Dependent variable

$\mathrm{Y}$ - is a binary dependent variable. It takes the value one if the acquisition was a PTP and zero if a company was acquired by other means. 
Independent variables:

PIND - is the percentage of independent non-executive directors on the board. To be defined as independent, a non-executive director must not have previously been an executive director of the company or an advisor to the company. Also excluded are directors that are related to executive directors or who work for firms with large shareholdings.

NX3 - is a binary variable that takes the value one if a company has at least three non-executive directors, at least two of which are independent, and zero otherwise. This is an alternative measure consistent with the 1998 Combined Code of Best Practice.

DUALITY - is a binary variable. It is equal to one if the posts of CEO and chairman are held by the same person and zero if they are not.

CODE - is a binary variable that measures the extent to which companies have adopted the Code's two key board structures. It has the value one if a company splits the posts of CEO and chairman and has at least three non-executive directors, two of which are independent, and zero if not.

FCF - measures a company's free cash flow. It is defined as the percentage of operating cash flow minus interest, taxes and dividends divided by sales in the period relating to the last accounts published prior to the acquisition.

SALESG - measures the company's growth prospects (Lehn and Poulsen, 1989). It is defined as the rate of growth of sales over the two years prior to being acquired.

TAKEOVER represents the market for corporate control and is defined in two ways (a) RUMOURS - is a dummy variable that takes a value of one if there had been press coverage of bid speculation in the period three months to fifteen months prior to 
the announcement of either a PTP transaction or of being acquired by an existing corporate group, and zero if not.

(b) TOINTENSITY measures the extent of takeover pressure faced by firms in their sector. It is the number of firms taken over in each Financial Times Classification category as a percentage of the number of firms in that category. ${ }^{9}$ This would also capture industry-specific effects such as the general market conditions, product life cycle effects and technological effects.

BRDSH - is the percentage of issued capital owned by the whole board. ${ }^{10}$

BRDSH 2 is the percentage of issued capital owned by the board deflated by total assets

VALUE - is a measure of the perceived undervaluation of the acquired firm. Based on Weir et al. (2005a), it is defined as the market capitalisation in the year prior to acquisition deflated by the market capitalisation in the previous year, which represents a benchmark year. If the ratio falls, this shows a reduction in the market valuation relative to the previous year.

\section{Control variables}

High capital expenditure is indicative of the use of funds on projects that will produce negative net present values (Halpern et al., 1999), because it suggests managerial discretionary behaviour. However, as Long and Ravenscraft (1993) and Lichtenberg and Siegel (1990) argue, lower capital expenditure will increase the ability of going private firms to service the increased post-PTP debt. Hence we introduce the control

\footnotetext{
${ }^{9}$ We would like to thank Professor Sudi Sudarsanam for this suggestion.

${ }^{10}$ Previous studies have generally used managerial ownership. Where the extent of shareholdings has been distinguished between executive and non-executive directors, the latter are typically extremely low. For example, O'Sullivan and Wong $(1998 ; 1999)$ finds the non-executive shareholdings in hostile targets are around $1-1.25 \%$ on average and in friendly targets and non-acquired firms are around 1.7$2.8 \%$. They also find that the size of non-executive shareholdings is insignificant in explaining differences between acquired and non-acquired firms and between friendly and hostile targets.
} 
variable, CAPEX, which measures net capital expenditure. It is defined as spending on new buildings, property and equipment minus depreciation, divided by the book value of total assets expressed as a percentage. We also control for size and industry (North, 2001). Size is LNTA, the natural log of total assets.

Industry effects influence takeover activity (Mitchell and Mulherin, 1996). These were initially going to be measured by industry dummies. However, the small number of PTPs in certain sectors created a singular matrix. To overcome this problem, significant numbers of sectors would have had to be omitted from the regressions. For example in Table 3, 30\% of the sector classifications would have had to be omitted. In Table 4, 35\% of the high Board shareholdings sectors would have had to be omitted and $40 \%$ from the low board shareholding sectors. It was concluded that the loss of so many sectors would have cast doubt on the results, so industry effects are measured by takeover pressure in the firm's sector. Thus TOINTENSITY was also used to measure industry effects because a significantly higher, or lower, value will indicate industry differences.

\section{(iii) Methodology}

Given the binary dependent variable, the analysis was undertaken using logistic regression. In logistic regression, the probability of a firm being involved in a $\mathrm{PTP}, \mathrm{P}_{\mathrm{i}}$, is the expected value that a firm is involved in a PTP given the values of the explanatory variables $\mathrm{X}_{\mathrm{i}}$

$$
\begin{aligned}
& P_{i}=E\left\langle y_{i}=1 \mid X_{i}\right\rangle \\
& =\frac{1}{1+e^{-y_{i}}}
\end{aligned}
$$


Where $\mathrm{E}$ is the expected value, $\mathrm{y}_{\mathrm{i}}=1$ is a firm going private and $\mathrm{X}_{\mathrm{i}}$ is a $\mathrm{N} \mathrm{x} \mathrm{k} \mathrm{matrix} \mathrm{of}$ independent explanatory variables.

We report the logit coefficients for $y_{i}$

The general model estimated is:

$y_{i}=\beta_{0}+\beta_{1} S_{A L E S G_{i}}+\beta_{2}$ FCF $_{i}+\beta_{3}$ PIND $_{i}+\beta_{4} D U A L_{i}+\beta_{5}$ BRDSH $_{i}$

$+\beta_{6}$ VALUE $_{i}+\beta_{7}$ RUMOURS $_{i}+\beta_{8}$ LNTA $_{i}+\beta_{9}$ CAPEX $_{i}$

Other model specifications analysed included the variables:

$\beta_{10}$TOINTENSITY $_{i}, \beta_{11} N X 3_{i}, \beta_{12}$ CODE $_{i}$

Given the first set of hypotheses discussed above, we expect the following for the disciplinary and substitutability hypothesis -

$\beta_{1}<0, \beta_{2}>0, \beta_{3}<0, \beta_{4}>0, \beta_{5}<0, \beta_{6}<0, \beta_{7}>0, \beta_{10}>0, \beta_{11}<0, \beta_{12}<0$

$\beta_{8}$ and $\beta_{9}$ are not specified a priori as they are control variables.

Thus it is hypothesised that PTPs are more likely to have lower growth (SALESG), higher free cash flows (FCF), fewer independent non-executive directors (PIND and NX3), a greater incidence of duality (DUALITY), lower board ownership (BRDSH), lower market valuation (VALUE) and be more likely to experience takeover speculation (RUMOURS and TOINTENSITY) than other traditional acquisitions. No sign is specified for size (LNTA) or for capital expenditure (CAPEX). We also expect that PTPs are less likely to comply with the Code (CODE). The signs on the coefficients are explained in Table 1 Panel A.

For the second set of hypotheses relating to the non-disciplinary and complementarity hypothesis, we expect:

$$
\beta_{1}=0, \beta_{2}=0, \beta_{3}=0, \beta_{4}=0, \beta_{5}>0, \beta_{6}<0, \beta_{7}=0, \beta_{10}=0, \beta_{11}=0, \beta_{12}=0
$$

$\beta_{8}$ and $\beta_{9}$ are not specified a priori as they are control variables. 
Thus PTPs are more likely to have higher board ownership (BRDSH) and lower valuation (VALUE) that other traditional acquisitions. With the exception of size, (LNTA) and capital expenditure (CAPEX) for which no signs are specified, all other variables are expected to be insignificant. The signs on the coefficients are explained in Table 1 Panel B.

\section{INSERT TABLE 1}

\section{Empirical results}

(i) Sample characteristics

\section{INSERT TABLE 2}

Table 2 reports the sample descriptives and univariate analysis. In terms of ownership, the mean BOARDSHARE is $11.11 \%$ with $20 \%$ of the sample having board shareholdings in excess of $20 \%$. The board structure statistics show that $20 \%$ of the sample have one person undertaking the dual roles of CEO and chairman. Boards have an average of $39 \%$ independent non-executive directors, above the one third recommended in the Combined Code. We also find that $62 \%$ have at least three nonexecutive directors, of which at least two were independent. Further, 53\% combine no duality with at least three non-executive directors and two independent non-executive directors.

In terms of pressure from the market for corporate control, $31 \%$ of firms experience press rumours about possible takeover in the previous year. Average sales growth is $9.2 \%$ with $32 \%$ of the sample experiencing falling sales indicating poor growth prospects. The mean free cash flow for the sample is $3.59 \%$ with $84 \%$ of firms having positive free cash flows. On average, the sample valuation measure VALUE is 0.99 . Some $59 \%$ of the sample have valuation measures below 0.95 , with $55 \%$ below 0.90 , 
which suggests that targets in general experience falling market valuations prior to acquisition.

In terms of capital expenditure, the mean figure is $5.56 \%$ with $28 \%$ of firms spending in excess of $10 \%$ of the value of their assets on capital projects. The mean size of acquired firms is $£ 289.17$ million.

Univariate comparison of PTPs and acquired firms is undertaken using median, nonparametric Mann-Whitney and chi square tests. In relation to the disciplinary framework hypothesis, we find insignificant differences in free cash flow. There is also no difference in the extent to which the two groups experience takeover speculation. Neither is there any significant difference in the takeover intensity in different sectors. We find only one PTP is the result of an actual hostile takeover (Hillsdown), with another being accepted rather than incur a hostile fight (Sears). In addition, if we define takeover pressure in terms of actual previous unsuccessful bids, only $5 \%$ of firms going private are specifically reported as receiving a failed hostile bid in the previous year. This is consistent with Maupin et al. (1984) who find that PTPs are predominately friendly. In terms of traditional acquisitions of listed corporations, again only $5 \%$ are actually reported as having had a failed hostile bid in the previous year. These figures are in line with the low level of hostile take-overs in the UK. Press speculation therefore suggests a reasonably active market for corporate control but the lack of failed bids does not suggest that going private is a response to fear of takeover and an active market for corporate control. There is also no difference in relation to valuation or the percentage of independent non-executive directors but we find lower growth prospects, higher duality and that PTPs have a lower incidence of adoption of the 1998 Combined Code. 
In terms of the non-disciplinary framework, we find that PTPs have significantly higher board shareholdings than traditional acquisitions of listed corporations. Sales growth is also significantly lower for PTPs. In terms of board structure, we report that firms going private have a significantly higher frequency of duality and fewer nonexecutive directors, although the latter is not significant. However, both PTPs and traditional acquisitions of listed corporations have more than the recommended minimum percentage of non-executive directors. The NX3 dummy is also insignificant. Firms going private have significantly fewer cases of adopting both of the 1998 Combined Code's recommended board structures. These results offer support for our initial hypotheses in relation to the non-disciplinary framework. These results therefore indicate that we can differentiate between PTPs and traditional acquisitions of listed corporations in an environment where there is a general absence of hostile takeovers.

\section{INSERT TABLE 3}

\section{(ii) Multivariate results}

Table 3 presents the logistic regression results. A number of models are tested. Model 1 shows the basic analysis. Model 2 introduces an alternative market for corporate control variable, TOINTENSITY. Models 3 and 4 analyse the impact of alternative specifications of the 1998 Combined Code of Best Practice using NX3 and CODE, respectively.

We find little support for the disciplinary framework hypotheses. The results show that PTPs are more likely to have significantly lower growth prospects as measured by SALESG and more duality than traditional acquisitions of listed corporations. There 
is also some evidence of lower valuations. However, we find no difference in relation to free cash flows ${ }^{11}$, the percentage of non-executive directors with both measures being insignificant, takeover speculation, both measures are insignificant, or the adoption of the Combined Code's recommendations. In addition, they are also more likely to have significantly higher board shareholdings than traditional acquisitions of listed corporations. PTPs also have significantly lower valuations than traditional acquisitions of listed corporations. The results therefore suggest that the traditional disciplinary framework argument for going private does not explain UK PTPs.

In terms of the non-disciplinary framework, we find that board shareholdings are higher for PTPs and valuation is lower, both as hypothesised. However, we do find that PTPs are more likely to combine the posts of CEO and chairman. ${ }^{12}$ The insignificant results for free cash flows, takeover speculation, non-executive director representation and Combined Code adoption all lend weight to the framework. The positive coefficient for duality may reflect the fact that firms going private tend to be younger and are therefore more likely to have founders still in post (Weir et al. 2005b). It may, in the Combined Code period, with its comply and explain approach, also reflect an acceptance by shareholders that internal governance mechanisms are appropriate for the company and should not be regarded as a negative attribute. Given the increased awareness of corporate governance issues, the existence of duality may indicate a positive statement by shareholders. All models are significant at the $1 \%$ level.

\footnotetext{
${ }^{11}$ We also test a different definition of free cash flow. Capital expenditure may also represent spending on negative net present value projects so we combined free cash flow and capital expenditures. The variable was insignificant in all equations suggesting that the lack of importance of free cash flow is not sensitive to changes in definition.

12 The results are therefore consistent with studies such as Kini et al. (1995) and Weir et al. (2002) that show substitutability between agency mechanisms.
} 
The results therefore show that we can differentiate between PTPs and traditional acquisitions of listed corporations and that the differences can be explained within a framework in which we see the decline of the disciplinary takeover as a substitute for ineffective governance. The differences are consistent with non-disciplinary acquisitions which act as a complement to improving governance.

\section{Analysis Development}

The analysis was developed in three ways. First, in terms of board shareholdings; second in relation to differences between MBOs, MBIs and traditional acquisitions of listed corporations; and third in terms of the actual hostile pressure. The disciplinary hypothesis argues that it will be difficult to replace entrenched management because their high insider ownership and voting rights may protect them from the threat of takeover (Fama and Jensen, 1983).We therefore expect that firms going private, that have high board shareholdings, will not experience pressure from the threat of takeover. It is, however, expected that, consistent with Jensen (1986), they will have higher free cash flows and lower growth opportunities than traditional acquisitions of listed corporations. It is also maintained that management will have a financial incentive to go private, given their higher shareholdings. We find support for this given that the mean value of shareholdings for high ownership PTPs is $£ 23.2$ million whereas the mean value for traditional acquisitions of listed corporations is $£ 6.67$ million, $(\mathrm{Z}=5.69, \mathrm{p}<.001)$.

The disciplinary framework also argues that at low levels of inside ownership, inside owners pursue non-value maximising objectives by consuming large amounts of perks 
and/or engaging in suboptimal investment behaviour. Therefore, there is a misalignment of interests at both low and high levels of internal ownership.

Within a non-disciplinary framework, we expect no evidence of outside takeover pressure for PTPs with high board ownership. This is consistent with buyers being put off by the possibility of being faced with a board that may not be willing to sell. We also expect that these PTPs will experience lower valuations relative to traditional acquisitions of listed corporations. In contrast, firms involved in PTPs that have low board shareholdings, are unlikely to be entrenched and will not be able to so easily resist a bid. We would therefore expect that there will be no significant difference between these firms and traditional acquisitions of listed corporations, since both are targets that involve outside management buying into the firm.

To analyse the impact of board ownership, firms involved in PTPs were split into two clusters, high and low board ownership. ${ }^{13}$ Cluster analysis was used to identify groups within data. Firms were included in a particular cluster by minimising its Euclidean, or straight line, distance from the cluster's mean.

The PTP low board shareholding cluster has a mean of $6.46 \%$ and the high ownership cluster a mean of $44.54 \%$. The difference is significant at $1 \%$ indicating that PTPs can be split into two groups according to board shareholding ( $Z$ equals 5.93 and $p<.000$ ). The high board cluster includes PTP board shareholdings greater than or equal to

\footnotetext{
${ }^{13}$ Morck et al. (1988) use piecewise regression but recognise that there is an element of trial and error in finding the appropriate turning point(s). Halpern et al. (1999) use cluster analysis to split PTP board shareholdings into high and low board ownership. We follow this approach.
} 
$27.5 \%$ with the low shareholding group being less than $27.5 \%$. The low ownership cluster includes 69 PTPs and the high ownership cluster has 27 PTPs.

\section{INSERT TABLE 4}

Table 4 presents the logistic regression results for both of the board shareholdings sub-samples. As in Halpern et al. (1999), each PTP cluster is regressed against all traditional acquisitions of listed corporations. We find that firms going private that are in the large cluster are smaller than the traditional acquisitions of listed corporations (Mann Whitney $\mathrm{Z}=1.95, \mathrm{p}=0.05$ ). Given that smaller firms are likely to have higher board ownership, Mikkelson and Partch (1989) and Song and Walkling (1993), we deflate board ownership by total assets to take account of potential size effects (variable BRDSH2).

Splitting the sample into high and low ownership PTPs reveals significant differences between the PTP subgroups and traditional acquisitions of listed corporations. High board ownership PTPs have significantly higher board ownership concentration, higher free cash flows and lower growth prospects. As expected, we find no evidence of pressure from outside bidders for high board ownership firms going private. There is evidence that duality is more common and that PTPs are less likely to have at least three non-executive directors, two of whom are independent. The negative CODE variable also shows that PTPs are less likely to have adopted the recommended board structures as laid down in the 1998 Combined Code of Best Practice.

However, the average number of independent non-executive directors for high board ownership PTPs is 2.03, which is at the level recommended in the 1998 Combined 
Code. The key factor in the governance structure is that $44 \%$ of high board ownership PTPs have duality whereas only $14 \%$ of traditional acquisitions of listed corporations have it. The extent to which this is undesirable, however, is not clear given that the Hampel (1998) recognises that duality may be appropriate for small firms. High board ownership PTPs are smaller than traditional acquisitions of listed corporations so that the results do not suggest poor governance, merely different governance structures. Given that 25 out of 27 (93\%) PTPs in the high board shareholding group are management buy-outs (MBOs), the results suggest that going private is driven by management that has a different perspective on the advantages of remaining public. ${ }^{14}$

As expected, the low board shareholdings PTPs exhibit no significant differences relative to traditional acquisitions of listed corporations. Given the involvement of outside buyers, and the lack of hostility, there is no reason to differentiate between the choice of targets. What is not clear is why some firms went private and others did not. There are, however, a number of possibilities. First, the buyer is a private company, for example Philip Green's purchase of Sears. Second, the specialist knowledge of a venture capitalist may make certain firms more attractive. Third, the amount of funding required is small enough to make venture capitalists interested.

The second development relates to the fact that so many of the high board shareholding cluster were MBOs, which raises the issue of whether or not there are separate identifiable sub groups even within PTPs. This was analysed by means of multinomial logistic regression which allows us to separate data into more than two

\footnotetext{
14 The regressions were run using just the 25 management buy-outs. The results were similar to those discussed above.
} 
categories. In this case there are three choices - MBO, MBI and traditional acquisitions of listed corporations.

Greene (1997) shows

$$
\operatorname{Pr}\left(y_{i}=j\right)=\frac{\exp \left(\beta_{j}^{\prime} X_{i}\right)}{1+\sum_{k=1}^{j} \exp \left(\beta_{j}^{\prime} X_{i}\right)}
$$

where

Pr is probability, $\mathrm{i}$ is the $\mathrm{i}^{\text {th }}$ firm and $\mathrm{j}$ is the $\mathrm{j}^{\text {th }}$ outcome and $\mathrm{k}$ is number of outcomes, which in our case, $3, \mathrm{MBO}, \mathrm{MBI}$ or traditional acquisitions of listed corporations. $\mathrm{X}_{\mathrm{i}}$ is the matrix of explanatory variables Therefore, the model measures the probability $\left(\mathrm{P}_{\mathrm{i}}\right)$ that a firm will belong to outcome $\mathrm{j}$, an MBO or MBI, rather than a traditionally acquired firm, given characteristics $\mathrm{X}_{\mathrm{i}}$. The reference group was traditionally acquired firms in both cases so that the regressions produce two sets of coefficients, the first referring to MBOs relative to traditional acquisitions of listed corporations and the second to MBIs relative to traditional acquisitions of listed corporations. To overcome the problem of indeterminacy, the normalisation $\beta_{0}=0$ is used, Greene (1997). The multinomial logistic results are given in Table 4. We only report the MBO-traditional acquisitions of listed corporations results because the period under study was one in which non-hostile acquisitions were the norm. Given, that MBIs involve external buyers, we expect them to exhibit the characteristics associated with a friendly takeover, relative to traditional acquisitions of listed corporations. In this case, we would not expect any differences between MBIs and traditional acquisitions of listed corporations. The results support this. We find no significant differences between MBIs and traditional acquisitions of listed corporations in terms of growth prospects, board structure characteristics, takeover speculation, board ownership, free cash flows 
or capital expenditure. All variables and equations for MBIs were insignificant and hence are not reported.

\section{INSERT TABLE 5}

Table 5 shows that MBOs are more likely to have significantly higher board shareholdings than traditional acquisitions of listed corporations. The shareholding result is consistent with that in Table 3 given that MBOs dominate the PTP sample and tend to exhibit higher board shareholdings than MBIs $(22.02 \%$ and $7.78 \%$ respectively, $\mathrm{t}=3.59, \mathrm{p}=0.01$ ). They also have fewer non-executive directors. However, MBOs do have an average of $32.5 \%$ non-executive directors on their boards, which shows that they are not out of step with the recommended one third of the 1998 Combined Code. However, MBOs are more likely to have the same person acting as CEO and chairman and the negative CODE variable shows that they are less likely to adopt both recommended board structures. It is also found that MBOs are not more likely to experience takeover rumours than traditional acquisitions of listed corporations. Nor are they undervalued, have higher free cash flows or experience lower growth relative to traditional acquisitions of listed corporations.

These results suggest that MBO managers have inside information, which is not known to the market and that they believe that the market's long-term view of the company is incorrect. This is consistent with anecdotal statements by private equity financiers of public to private MBOs (CMBOR, 1999). Therefore, there is an incentive to buy out the company and to remain in charge of it rather than let the market continue to undervalue it, as perceived by the management. 
The third development relates to the way in which pressure from the market for corporate control is measured. The speculation variable refers to the reporting of press takeover speculation. However, press rumours tend to be vague and non-specific and merely state that there is speculation of a bid. Usually there is little concrete information about, for example, who the possible bidder might be. It may be that the rumours relate to a possible $\mathrm{MBO}$ rather than an outside, hostile buyer. Therefore to address that point, a new variable was calculated which had the value one if there had been a failed hostile bid during the previous year and zero if there had not. It was run for all the models in Tables 2, 3 and 4 and was insignificant in all of them. Thus there was no significant hostile pressure for PTPs in general, MBOs or MBIs which provides further support for the non-disciplinary framework providing a suitable means within which to analyse takeover activity.

\section{Conclusions}

This paper has explored the governance and other characteristics of acquired quoted firms during a period in which the vast majority of publicly quoted acquisitions were non-hostile and where there had been developments in internal governance. Given that PTPs are regarded as a response to a hostile takeover threat, and the late 1990s witnessed the growth of non-hostile takeovers, we developed a first set of propositions (H1a to H1f) relating to expected differences between PTPs and traditional acquisitions of listed corporations by existing corporate groups from a disciplinary perspective where the external takeover market is expected to substitute for weaknesses in internal governance. We developed a second set of propositions (H2a to $\mathrm{H} 2 \mathrm{f}$ ) relating to the expected differences concerning the same set of variables between PTPs and traditional acquisitions of listed corporations by existing corporate 
groups from a non-disciplinary perspective where the external takeover market is expected to complement internal governance mechanisms.

Supporting the disciplinary/substitution perspective, PTPs are more likely to have lower growth prospects than traditional acquisitions of listed corporations by existing corporate groups (hypothesis H1a is supported but hypothesis H2a is not supported). In contrast, supporting the non-disciplinary/complementarity perspective, PTPs are not more likely to have greater free cash flows than traditional acquisitions of listed corporations by existing corporate groups (Hypothesis H1b is not supported but hypothesis $\mathrm{H} 2 \mathrm{~b}$ is supported). With respect to the role of internal governance mechanisms, we find support for the non-disciplinary/complementarity perspective as PTPs do not have sub-optimal internal corporate governance structures in terms of lower proportions of outside directors but are more likely to have duality of CEO and Chair. ${ }^{15}$ (Hypothesis H1c is not supported but hypothesis H2c is supported). The nondisciplinary/complementarity perspective is further supported as PTPs are more likely to have higher board ownership (hypothesis H1d is not supported but hypothesis H2d is supported). There is mixed support across different model specifications for hypotheses H1e and H2e relating to whether PTPs are more likely to be undervalued or not, and thus no clear support for one perspective in preference to the other. With respect to external governance, PTPs are not more likely to experience takeover speculation or more hostile interest. Hence these firms are not under greater disciplinary pressure from the market for corporate control, indicating support for the non-disciplinary/complementarity perspective (hypothesis H1f is not supported but

\footnotetext{
${ }^{15}$ It was argued that duality may be regarded positively in an age of greater corporate governance awareness.
} 
hypothesis $\mathrm{H} 2 \mathrm{f}$ is supported). These findings are contrary to the view that hostile takeovers substitute for weaknesses in internal corporate governance. .

Further insights were gained by separating PTPs into high/low board shareholdings and MBOs/MBIs. Splitting PTPs into high and low board shareholding groups provides evidence that the boards in firms going private appear to be entrenched, particularly when board shareholdings are high. It was also shown that MBOs have higher board ownership and fewer non-executive directors than traditional acquisitions of listed corporations. However, their non-executive director representation complies with the 1998 Combined Code of Best Practice, which indicates that non-executive director representation is not sub-optimal. However, they have more duality but given the Combined Code's 'comply and explain' basis, duality may not necessarily be undesirable.

The results therefore offer support for the argument that internal governance and the rise in friendly takeovers are complementary. The growth in public-to-private activity in the UK occurred when hostile takeovers were rare and where compliance with internal governance codes was high. Our findings, raise the prospect that an important explanation for going private by $\mathrm{MBO}$ is that incumbent management possess private information, which leads them to believe that the market has an incorrect perspective of the company's prospects. A delisting would therefore enable the management to operate in conditions that did not carry with them the public perception that the company was a poor performer. As hypothesised, MBIs did not have different governance and ownership characteristics and are no different from traditional 
acquisitions of listed corporations. This suggests that MBIs simply provide an additional form of external acquisition vehicle

Our results raise a number of additional research questions. First, the extent of CEO and other executive director turnover post-PTP may provide additional insights into the desire to avoid public monitoring by going private. Second, it may also be worth exploring directly whether PTPs take place as a result of the regulatory burden of being listed. The finding of higher board shareholdings in PTPs, together with anecdotal evidence, hints that disaffected entrepreneurs, who remain in control of listed companies, delist them to economise on regulatory costs and to implement restructuring and growth strategies away from the public gaze. 


\section{References}

Baliga, B., Moyer, R. and Rao, R. (1996). 'CEO duality and firm performance: what's the fuss?' Strategic Management Journal, 17: 41-53.

Boone, A.L., Mulherin, J.H. (2002). 'Corporate restructuring and corporate auctions'. Working Paper College of William and Mary.

Boyd, B.K. (1995). 'CEO duality and firm performance'. Strategic Management Journal, 16: 301-312.

Cadbury (1992). Report of the Committee on the Financial Aspects of Corporate Governance. (Chaired by Sir Adrian Cadbury). London: Gee.

CMBOR (1999). 'Recent developments in the UK public to private market. Quarterly Review from the Centre for Management Buy-out Research, Nottingham University Business School, Winter 1998/99, pp.19-40.

CMBOR (2003). Quarterly Review from the Centre for Management Buy-out Research, Nottingham University Business School, Spring.

Combined Code (2003). The Combined Code on Corporate Governance. London: Financial Reporting Council, London.

Committee on Corporate Governance (1998). The Combined Code. London: London Stock Exchange Limited, Gee, London.

Corporate Register (1998, 1999, 2000, 2001) PricewaterhouseCoopers, Hemmington Scott

Dahya, J. and Powell, R. (1999). Top Management Changes Following Hostile and Friendly Takeovers. ACCA Research Report, 61, London.

Dahya, J., McConnell, J.J. and Travlos, N.G. (2002). 'The Cadbury Committee, corporate performance and top management turnover'. Journal of Finance, 57: 461483. 
DeAngelo, H., DeAngelo, L. and Rice, E. (1984). 'Going private: minority freeze outs and stockholders' wealth'. Journal of Law and Economics, 27: 367-402.

Dedman, E. (2003). 'Executive turnover in UK firms: the impact of Cadbury'. Accounting and Business Research, 33: 33-50.

Ezzamel, M. and Watson, R. (2005). 'Boards of directors and the role of nonexecutive directors in the governance of corporations'. Ch. 5 in Keasey, K., Thompson, S. and Wright, M. (eds) Corporate Governance: Accountability, Enterprise and International Comparisons. London: Wiley.

Fama, E. (1980). 'Agency problems and the theory of the firm'. Journal of Political Economy, 88: 134-145.

Fama, E. and Jensen M. (1983). 'Separation of ownership and control'. Journal of Law and Economics, 26: 301-349.

Frankfurter, G. and Gunay, E. (1992). 'Management buyouts: the sources and sharing of wealth between insiders and outside shareholders'. Quarterly Review of Economics and Finance, 32: 163-181.

Franks, J. and Mayer, C. (1996). 'Hostile takeovers and the correction of managerial failure'. Journal of Financial Economics, 40: 163-181.

Greenbury Report, The (1995) Directors' Remuneration (report of a study chaired by Sir Richard Greenbury), Gee, London

Greene, W.E. (1997). Econometric Analysis (3 ${ }^{\text {rd }}$ ed). London: Prentice Hall Inc.

Halpern, P. Kieschnick, R. and Rotenberg, W. (1999). 'On the heterogeneity of leveraged going private transactions'. Review of Financial Studies, 12: 281-309.

Hampel, R. (1998). Committee on Corporate Governance: Final Report. London: Gee. 
Jensen M. (1986). 'Agency costs and free cash flow, corporate finance and takeovers'. American Economics Review, 76: 323-329.

Kaplan, S. (1989). 'Management buyouts: evidence on taxes as a source of value'. Journal of Finance, 64: 611-632.

Kennedy, V. and Limmack, R. (1996). 'Takeover activity CEO turnover and the market for corporate control'. Journal of Business Finance and Accounting, 23: 267293.

Kieschnick, R. (1998). 'Free cash flow and stockholder gains in going private transaction revisited'. Journal of Business Finance and Accounting, 25: 187-202.

Kini, O., Kracaw, W. and Mian, S. (1995). 'Corporate takeovers, firm performance and board composition'. Journal of Corporate Finance, 1: 383-412.

Kini, O., Kracaw, W. and Mian, S. (2004). 'The nature of discipline in corporate takeovers'. Journal of Finance, 59: 1511-1552.

Lehn, K. and Poulsen, A. (1989). 'Free cash flow and stockholder gains in going private transactions'. Journal of Finance, XLIV: 771-787.

Lichtenberg, F.R. and Siegel, D. (1990). 'The effects of leveraged buyouts on productivity and related aspects of firm behaviour'. Journal of Financial Economics, 26: $165-194$.

Long, W.F. and Ravenscraft, D.J. (1993). 'LBOs, debt and R and D intensity'. Strategic Management Journal, 14 (special issue): 119-135.

Manne, H.G. (1965), 'Mergers and the market for corporate control'. Journal of Political Economy, 73: 110-120.

Martin, K.J, and McConnell, J.J (1991). 'Corporate performance, corporate takeovers and management turnover'. Journal of Finance, XLVI: 671-687. 
Maupin, R., Bidwell, C. and Ortegren, A. (1984). 'An empirical investigation of the characteristics of publicly quoted corporations which change to closely held ownership through management buyouts'. Journal of Business Finance and Accounting, 11: 345-359.

Mikkelson, W. and Partch, M. (1989). 'Managers' voting rights and corporate control'. Journal of Financial Economics, 25: 263-290.

Mitchell, M. L. and Mulherin, J. H. (1996). 'The impact of industry shocks on takeover and restructuring activity'. Journal of Financial Economics, 41: 193-229. Morck, R., Shleifer, A. and Vishny, R. (1988). 'Characteristics of targets and friendly take-overs'. In Auerbach, A.J. (ed). Corporate Take-overs: Causes and Consequences, Chicago, University of Chicago Press.

North, D. (2001). 'The role of managerial incentives in corporate acquisitions: evidence from the 1990s'. Journal of Corporate Finance, 7: 125-149.

Nuttall, R. (1999). 'Takeover likelihood models for UK quoted companies'. Nuffield College Working Paper, University of Oxford.

Opler, T. and Titman, S. (1993). 'The determinants of leveraged buyout activity: free cash flow vs. financial distress costs'. Journal of Finance, XLVIII: 1985-1999.

O’Sullivan, C.N. and Wong, P. (1998). 'Internal versus external control: An analysis of board composition and ownership in UK takeovers'. Journal of Management and Governance, 2: 17-35.

O'Sullivan, C.N. and Wong, P. (1999). 'Board composition, ownership structure and hostile takeovers: Some UK evidence'. Accounting and Business Research, 29(2): 139-155. 
O'Sullivan, C.N. and Wong, P. (2005). 'The governance role of takeovers'. Ch.8 in Keasey, K., Thompson, S. and Wright, M. (eds) Corporate Governance: Accountability, Enterprise and International Comparisons. London: Wiley.

Palepu, K.G. (1986). 'Predicting take-over targets: a methodological and empirical analysis'. Journal of Accounting and Economics, 8: 3-35.

Peasnell, K.V., Pope, P.F. and Young, S. (2003). 'Managerial equity ownership and the demand for outside directors'. European Financial Management, 9: 99-118. Powell, R.G. (1997). 'Modelling take-over likelihood'. Journal of Business Finance and Accounting, 24: 1009-1030.

Rosenstein, S. and Wyatt, J.G. (1990). 'Outside directors, board independence and shareholder wealth'. Journal of Financial Economics, 26: 175-191.

Sahlman, W. A. (1990). 'The structure and governance of venture-capital organizations'. Journal of Financial Economics, 27: 473-521.

Schwert, G. W. (2000). 'Hostility in take-overs: in the eyes of the beholders'. Journal of Finance, 55: 2599-2640.

Shivdasani, A. (1993). 'Board composition, ownership structure and hostile takeovers'. Journal of Accounting and Finance, 16: 167-198.

Short, H., Keasey, K., Wright, M. and Hull, A. (1999). 'Corporate governance: from accountability to enterprise'. Accounting and Business Research, 29: 337-352.

Song, M. and Walkling, R. (1993). 'The impact of managerial ownership on acquisition attempts'. Journal of Financial and Quantitative Analysis, 28: 439-457.

Sudarsanam, S. (2003). Creating Value from Mergers and Acquisitions: The Challenges. London: FT:Prentice Hall, ch. 21. 
Sudarsanam, P.S. and Mahate, A.A. (2003). 'Glamorous acquirers, method of payment and post-acquisition performance: the UK evidence'. Journal of Business Finance and Accounting, 30: 329-341.

Torabzadeh, D. and Bertin, W. (1987). 'Leveraged buyouts and shareholder returns'. Journal of Financial Research, 20: 313-319.

Vafeas, N. and Theodorou (1998). 'The relationship between board structure and firm performance in the UK'. British Accounting Review, 30: 383-407.

Weir, C. (1997). 'Corporate governance, performance and take-overs: an empirical analysis of UK mergers'. Applied Economics, 29: 1465-1475.

Weir, C., Laing, D. and McKnight, P.J. (2002). 'Internal and external governance mechanisms: their impact on the performance of large UK public companies'. Journal of Business Finance and Accounting, 29: 579-611.

Weir, C. and Laing, D. (2003). 'Ownership structure, board composition and the market for corporate control in the UK: an empirical analysis'. Applied Economics, 35: $1747-1759$.

Weir, D., Laing, D. and Wright, M. (2005a). 'Undervaluation, private information, agency costs and the decision to go private'. Applied Financial Economics, 15: 947961.

Weir, C, Laing, D. Wright, M. and Burrows, A. (2005b). 'Financial distress costs, incentive realignment, private equity and the decision to go private. Public to private activity in the UK'. Working Paper, SSRN.

Wright, M. and Robbie, K. (1998). 'Venture capital and private equity: A review and synthesis'. Journal of Business Finance and Accounting, $25(5$ \& 6): 521-570. 
Table 1: Summary of hypotheses and expected directions of relationships

Panel A: Disciplinary perspective

COEFFICIENT EXPECTATION EXPLANATION

\begin{tabular}{|c|c|c|}
\hline$\beta_{1}$ & Negative & $\begin{array}{l}\text { A lower SALESG indicates higher agency costs } \\
\text { (hypothesis H1a) }\end{array}$ \\
\hline$\beta_{2}$ & Positive & $\begin{array}{l}\text { A greater FCF indicates higher agency costs } \\
\text { (hypothesis } \mathrm{H} 1 \mathrm{~b} \text { ) }\end{array}$ \\
\hline$\beta_{3}$ & Negative & $\begin{array}{l}\text { a greater PIND indicates more effective internal } \\
\text { board governance (hypothesis H1c) }\end{array}$ \\
\hline$\beta_{4}$ & Positive & $\begin{array}{l}\text { DUALITY indicates less effective internal board } \\
\text { governance (hypothesis H1c). }\end{array}$ \\
\hline$\beta_{5}$ & Negative & $\begin{array}{l}\text { A lower BRDSH indicates a lack of financial } \\
\text { incentive effects (hypothesis H1d) }\end{array}$ \\
\hline$\beta_{6}$ & Negative & $\begin{array}{l}\text { A lower valuation indicates poorer stock market } \\
\text { performance (hypothesis H1e) }\end{array}$ \\
\hline$\beta_{7}$ & Positive & $\begin{array}{l}\text { Greater takeover speculation (RUMOURS) } \\
\text { indicates more effective external governance } \\
\text { (hypothesis H1f) }\end{array}$ \\
\hline$\beta_{8}$ & n.a. & $\begin{array}{l}\text { No hypothesised direction as control variable for } \\
\text { size of firm }\end{array}$ \\
\hline$\beta_{9}$ & n.a. & $\begin{array}{l}\text { No hypothesised direction as control variable for } \\
\text { amount of capital expenditure }\end{array}$ \\
\hline$\beta_{10}$ & Positive & $\begin{array}{l}\text { TOINTENSITY - an aternative measure to } \\
\text { RUMOURS for takeover pressure }\end{array}$ \\
\hline$\beta_{11}$ & Negative & $\begin{array}{l}\text { NX3 - an alternative measure to PIND for role of } \\
\text { non-executive directors }\end{array}$ \\
\hline$\beta_{12}$ & Negative & $\begin{array}{l}\text { CODE - a combined alternative measure to PIND } \\
\text { and DUALITY for internal governance }\end{array}$ \\
\hline
\end{tabular}


Panel B: Non-disciplinary perspective

\begin{tabular}{|c|c|c|}
\hline COEFFICIENT & EXPECTATION & EXPLANATION \\
\hline$\beta_{1}$ & Insignificantly & There will be no difference between the \\
\hline & $\begin{array}{l}\text { different from } \\
\text { zero }\end{array}$ & $\begin{array}{l}\text { SALESG of PTPs and other traditional } \\
\text { acquisitions. (hypothesis } \mathrm{H} 2 \mathrm{a} \text { ) }\end{array}$ \\
\hline$\beta_{2}$ & $\begin{array}{l}\text { Insignificantly } \\
\text { different from } \\
\text { zero }\end{array}$ & $\begin{array}{l}\text { There will be no difference in the extent of FCF } \\
\text { of PTPs and other traditional acquisitions. } \\
\text { (hypothesis } \mathrm{H} 2 \mathrm{~b} \text { ) }\end{array}$ \\
\hline$\beta_{3}$ & $\begin{array}{l}\text { Insignificantly } \\
\text { different from } \\
\text { zero }\end{array}$ & $\begin{array}{l}\text { There is no difference in the representation of } \\
\text { PIND of PTPs and other traditional acquisitions. } \\
\text { (hypothesis H2c) }\end{array}$ \\
\hline$\beta_{4}$ & $\begin{array}{l}\text { Insignificantly } \\
\text { different from } \\
\text { zero }\end{array}$ & $\begin{array}{l}\text { There will be no difference in the incidence of } \\
\text { DUALITY between PTPs and other traditional } \\
\text { acquisitions. (hypothesis H2c). }\end{array}$ \\
\hline$\beta_{5}$ & Positive & $\begin{array}{l}\text { BRDSH is more likely to be higher in PTPs that } \\
\text { in other traditional acquisitions. (hypothesis H2d) }\end{array}$ \\
\hline$\beta_{6}$ & Negative & $\begin{array}{l}\text { Perceived firm valuation is likely to be lower for } \\
\text { PTPs than for other traditional acquisitions. } \\
\text { (hypothesis H2e) }\end{array}$ \\
\hline$\beta_{7}$ & $\begin{array}{l}\text { Insignificantly } \\
\text { different from } \\
\text { zero }\end{array}$ & $\begin{array}{l}\text { There will be no difference in the extent of } \\
\text { RUMOURS of PTPs and other traditional } \\
\text { acquisitions. (hypothesis H2f) }\end{array}$ \\
\hline$\beta_{8}$ & n.a. & $\begin{array}{l}\text { No hypothesised direction as control variable for } \\
\text { size of firm }\end{array}$ \\
\hline$\beta_{9} \ldots$ & n.a. & $\begin{array}{l}\text { No hypothesised direction as control variable for } \\
\text { amount of capital expenditure }\end{array}$ \\
\hline$\beta_{10}$ & $\begin{array}{l}\text { Insignificantly } \\
\text { different from } \\
\text { zero }\end{array}$ & $\begin{array}{l}\text { TOINTENSITY }- \text { an alternative measure to } \\
\text { RUMOURS for takeover pressure }\end{array}$ \\
\hline$\beta_{11}$ & $\begin{array}{l}\text { Insignificantly } \\
\text { different from } \\
\text { zero }\end{array}$ & $\begin{array}{l}\text { NX3 - an alternative measure to PIND for role of } \\
\text { non-executive directors }\end{array}$ \\
\hline$\beta_{12}$ & $\begin{array}{l}\text { Insignificantly } \\
\text { different from } \\
\text { zero }\end{array}$ & $\begin{array}{l}\text { CODE - a combined alternative measure to PIND } \\
\text { and DUALITY for internal governance }\end{array}$ \\
\hline
\end{tabular}


SALESG is the percentage change in sales over the two years prior to being acquired. FCF is operating cash flow minus interest, taxes and dividend divided by sales. PIND is the percentage of independent non-executive directors on the board. DUALITY is a dummy variable that has a value of one of he posts of CEO and chairman are undertaken by a single person and zero if they are separated. BRDSH is the percentage of issued capital owned by the board. VALUE is the market capitalisation at the time of the last published accounts divided by the market capitalisation the year before. RUMOURS is a dummy variable that takes a value of 1 if there had been press coverage of bid speculation in the period three months to fifteen months prior to the announcement of the either going private or being acquired and zero if not. LNTA is the natural $\log$ of total assets. CAPEX is the percentage net capital expenditure over total assets. TOINTENSITY is the percentage of firms in an industrial sector that were taken over in a particular year. . NX3 is a dummy variable that takes the value 1 of a board has at least three non-executive directors of which at least two are independent and zero if not. CODE is a dummy variable that has the value 1 if a company has at least three non-executive directors, at least two of which are independent, and zero if not 
Table 2 Descriptives and univariate analysis

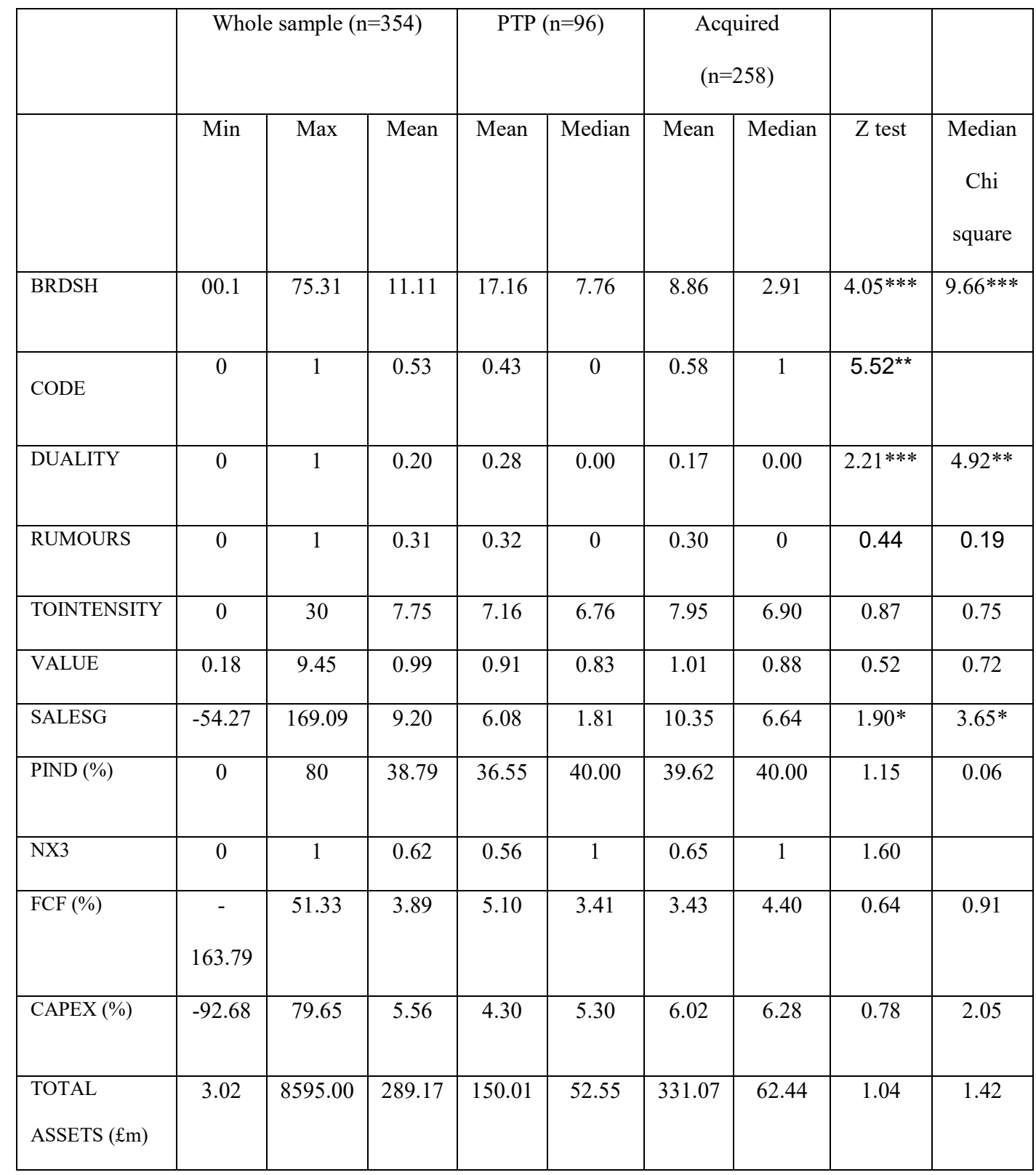

** - significant at the $5 \%$ level; *** - significant at the $1 \%$ level

Mann Whitney $Z$ test used for all variables except chi square test applied to the dummy variables CODE, NX3, DUALITY, RUMOURS, and TOINTENSITY.

No median test for CODE and NX3 because all values less than or equal to the median.

BRDSH is the percentage of issued capital owned by the board. CODE is a dummy variable that has the value 1 if a company has at least three non-executive directors, at least two of which are independent, and zero if not. DUALITY is a dummy variable that has a value of one of he posts of CEO and chairman are undertaken by a single 
person and zero if they are separated. RUMOURS is a dummy variable that takes a value of 1 if there had been press coverage of bid speculation in the period three months to fifteen months prior to the announcement of the either going private or being acquired and zero if not. TOINTENSITY is the percentage of firms in an industrial sector that were taken over in a particular year. VALUE is the market capitalisation at the time of the last published accounts divided by the market capitalisation the year before. SALESG is the percentage change in sales over the two years prior to being acquired. PIND is the percentage of independent non-executive directors on the board. NX3 is a dummy variable that takes the value 1 of a board has at least three non-executive directors of which at least two are independent and zero if not. FCF is operating cash flow minus interest, taxes and dividend divided by sales. CAPEX is the percentage net capital expenditure over total assets. TOTAL ASSETS is current assets plus fixed assets.. 
Table 3 Logistic regression explaining the differences between PTPs $(n=96)$ and traditional acquisitions of listed corporations $(\mathbf{n}=\mathbf{2 5 8})$

\begin{tabular}{|c|c|c|c|c|}
\hline & Model 1 & Model 2 & Model 3 & Model 4 \\
\hline RUMOURS & $\begin{array}{l}0.3616 \\
(1.29)\end{array}$ & & $\begin{array}{l}0.3593 \\
(1.28)\end{array}$ & $\begin{array}{l}0.3470 \\
(1.24)\end{array}$ \\
\hline TOINTENSITY & & $\begin{array}{c}-0.0252 \\
(0.84)\end{array}$ & & \\
\hline PIND & $\begin{array}{c}-0.0016 \\
(0.20)\end{array}$ & $\begin{array}{c}-0.0010 \\
(0.12)\end{array}$ & & \\
\hline NX3 & & & $\begin{array}{c}-0.0704 \\
(0.24)\end{array}$ & \\
\hline DUALITY & $\begin{array}{l}0.5938 \\
(1.93)^{*}\end{array}$ & $\begin{array}{l}0.5322 \\
(1.71)^{*}\end{array}$ & $\begin{array}{l}0.5925 \\
(1.93)^{*}\end{array}$ & \\
\hline CODE & & & & $\begin{array}{c}-0.4417 \\
(1.61)\end{array}$ \\
\hline FCF & $\begin{array}{l}0.0282 \\
(1.06)\end{array}$ & $\begin{array}{l}0.0108 \\
(0.92)\end{array}$ & $\begin{array}{l}0.0127 \\
(1.06)\end{array}$ & $\begin{array}{l}0.0137 \\
(1.10)\end{array}$ \\
\hline BRDSH & $\begin{array}{c}0.0381 \\
(4.23)^{* * *}\end{array}$ & $\begin{array}{c}0.0370 \\
(4.15)^{* * *}\end{array}$ & $\begin{array}{c}0.0381 \\
(4.27)^{* * *}\end{array}$ & $\begin{array}{c}0.0372 \\
(4.21)^{* * *}\end{array}$ \\
\hline LNTA & $\begin{array}{c}0.0084 \\
(0.08)\end{array}$ & $\begin{array}{c}0.0273 \\
(0.27)\end{array}$ & $\begin{array}{l}0.0126 \\
(0.12)\end{array}$ & $\begin{array}{c}0.0217 \\
(0.20)\end{array}$ \\
\hline CAPEX & $\begin{array}{c}-0.0058 \\
(0.64)\end{array}$ & $\begin{array}{c}-0.0057 \\
(0.62)\end{array}$ & $\begin{array}{c}-0.0056 \\
(0.62)\end{array}$ & $\begin{array}{c}-0.0050 \\
(0.55)\end{array}$ \\
\hline VALUE & $\begin{array}{l}-0.4112 \\
(1.69)^{*}\end{array}$ & $\begin{array}{c}-0.3995 \\
(1.57)\end{array}$ & $\begin{array}{l}-0.4131 \\
(1.69)^{*}\end{array}$ & $\begin{array}{c}-0.4131 \\
(1.62)\end{array}$ \\
\hline SALESG & $\begin{array}{c}-0.0123 \\
(1.90)^{*}\end{array}$ & $\begin{array}{l}-0.0131 \\
(2.02)^{* *}\end{array}$ & $\begin{array}{l}-0.0124 \\
(1.92)^{*}\end{array}$ & $\begin{array}{l}-0.0129 \\
(1.96)^{* *}\end{array}$ \\
\hline Constant & $\begin{array}{l}-1.2037 \\
(1.92)^{*}\end{array}$ & $\begin{array}{c}-0.9731 \\
(1.48)\end{array}$ & $\begin{array}{l}-1.2395 \\
(2.26)^{* * *}\end{array}$ & $\begin{array}{l}-0.9529 \\
(1.82)^{*}\end{array}$ \\
\hline Chi square & $34.76 * * *$ & $33.83 * * *$ & $34.77 * * *$ & $33.54 * * *$ \\
\hline
\end{tabular}

$\mathrm{t}$ values on parentheses

*** - significant at the $1 \%$ level; ** - significant at the $5 \%$ level; * - significant at the $10 \%$ level.

RUMOURS is a dummy variable that takes a value of 1 if there had been press coverage of bid speculation in the period three months to fifteen months prior to the announcement of the either going private or being acquired and zero if not. TOINTENSITY is the percentage of firms in an industrial sector that were taken over in a particular year. PIND is the percentage of independent non-executive directors on the board. NX3 is a dummy variable that takes the value 1 of a board has at least three non-executive directors of which at least two are independent and zero if not. DUALITY is a dummy variable that has a value of one if the posts of CEO and 
chairman are undertaken by a single person and zero if they are separated. CODE is a dummy variable that has the value 1 if a company has at least three non-executive directors, at least two of which are independent, and zero if not. FCF is operating cash flow minus interest, taxes and dividend divided by sales. BRDSH is the percentage of issued capital owned by the board. LNTA is the natural logarithm of total assets. CAPEX is the percentage net capital expenditure over total assets, where total assets current assets plus fixed assets. VALUE is the market capitalisation at the time of the last published accounts divided by the market capitalisation the year before. SALESG is the percentage change in sales over the two years prior to being acquired. 
Table 4 Impact of shareholdings on the probability of differentiating between PTPs and traditional acquisitions of listed corporations.

[High board shareholdings, PTP $\mathrm{n}=27$; low board shareholdings, $\mathrm{PTP}=69$. In both cases other traditional acquisitions of listed corporations $n=258]$.

\begin{tabular}{|c|c|c|c|c|c|c|}
\hline & \multicolumn{3}{|c|}{ High Board Shareholdings } & \multicolumn{3}{|c|}{ Low Board Shareholdings } \\
\hline & Model 5 & Model 6 & Model 7 & Model 8 & Model 9 & Model 10 \\
\hline RUMOURS & $\begin{array}{l}0.3137 \\
(0.60)\end{array}$ & $\begin{array}{c}0.3445 \\
(0.66)\end{array}$ & $\begin{array}{l}0.3764 \\
(0.73)\end{array}$ & $\begin{array}{l}0.1556 \\
(0.52)\end{array}$ & $\begin{array}{l}0.1558 \\
(0.52)\end{array}$ & $\begin{array}{l}0.1550 \\
(0.52)\end{array}$ \\
\hline PIND & $\begin{array}{c}-0.0293 \\
(1.63)\end{array}$ & & & $\begin{array}{c}-0.0023 \\
(0.25)\end{array}$ & & \\
\hline NX3 & & $\begin{array}{l}-1.0371 \\
(2.10)^{* *}\end{array}$ & & & $\begin{array}{c}-0.0799 \\
(0.26)\end{array}$ & \\
\hline DUALITY & $\begin{array}{c}1.2829 \\
(2.62)^{* * *}\end{array}$ & & & $\begin{array}{l}0.3467 \\
(0.99)\end{array}$ & $\begin{array}{l}0.3472 \\
(1.00)\end{array}$ & \\
\hline CODE & & & $\begin{array}{c}-1.7348 \\
(3.26)^{* * *}\end{array}$ & & ) & $\begin{array}{c}-0.3570 \\
(1.27)\end{array}$ \\
\hline FCF & $\begin{array}{l}0.0434 \\
(1.79)^{*}\end{array}$ & $\begin{array}{l}0.0479 \\
(1.94)^{*}\end{array}$ & $\begin{array}{c}0.0490 \\
(1.96)^{* *}\end{array}$ & $\begin{array}{l}0.0029 \\
(0.23)\end{array}$ & $\begin{array}{l}0.0029 \\
(0.23)\end{array}$ & $\begin{array}{l}0.0030 \\
(0.23)\end{array}$ \\
\hline VALUE & $\begin{array}{c}-0.8078 \\
(1.44)\end{array}$ & $\begin{array}{c}-0.8893 \\
(1.54)\end{array}$ & $\begin{array}{c}-0.8391 \\
(1.48)\end{array}$ & $\begin{array}{c}-0.1817 \\
(0.62)\end{array}$ & $\begin{array}{c}-0.1783 \\
(0.61)\end{array}$ & $\begin{array}{c}-0.1857 \\
(0.63)\end{array}$ \\
\hline BRDSH2 & $\begin{array}{c}0.3531 \\
(3.62)^{* * *}\end{array}$ & $\begin{array}{c}0.3614 \\
(3.78)^{* * *}\end{array}$ & $\begin{array}{c}0.3649 \\
(3.87)^{* * *}\end{array}$ & $\begin{array}{c}-0.1718 \\
(0.99)\end{array}$ & $\begin{array}{c}-0.1748 \\
(0.99)\end{array}$ & $\begin{array}{c}-0.1939 \\
(1.09)\end{array}$ \\
\hline SALESG & $\begin{array}{l}-0.0215 \\
(1.67)^{*}\end{array}$ & $\begin{array}{l}-0.0268 \\
(2.00)^{* *}\end{array}$ & $\begin{array}{l}-0.0287 \\
(2.10)^{* *}\end{array}$ & $\begin{array}{c}-0.0039 \\
(0.70)\end{array}$ & $\begin{array}{c}-0.0039 \\
(0.70)\end{array}$ & $\begin{array}{c}-0.0040 \\
(0.69)\end{array}$ \\
\hline CAPEX & $\begin{array}{l}0.0165 \\
(0.81)\end{array}$ & $\begin{array}{l}0.0227 \\
(1.13)\end{array}$ & $\begin{array}{c}0.0220 \\
(1.11)\end{array}$ & $\begin{array}{c}-0.0102 \\
(1.14)\end{array}$ & $\begin{array}{c}-0.0099 \\
(1.12)\end{array}$ & $\begin{array}{c}-0.0098 \\
(1.10)\end{array}$ \\
\hline Constant & $\begin{array}{l}-1.7236 \\
(2.08)^{* *}\end{array}$ & $\begin{array}{c}-2.0144 \\
(2.96)^{* * *}\end{array}$ & $\begin{array}{l}-1.5293 \\
(2.56)^{* *}\end{array}$ & $\begin{array}{l}-1.0279 \\
(1.95)^{*}\end{array}$ & $\begin{array}{c}-1.0720 \\
(2.65)^{* * *}\end{array}$ & $\begin{array}{c}-0.8464 \\
(2.31)^{* *}\end{array}$ \\
\hline Chi square & $35.57 * * *$ & $37.39 * * *$ & $23.76^{* * *}$ & 7.61 & 7.61 & 8.06 \\
\hline
\end{tabular}

$\mathrm{t}$ values in parentheses

$* * *$ - significant at the $1 \%$ level; ** - significant at the $5 \%$ level; * - significant at the $10 \%$ level

RUMOURS is a dummy variable that takes a value of 1 if there had been press coverage of bid speculation in the period three months to fifteen months prior to the announcement of the either going private or being acquired and zero if not. PIND is the percentage of independent non-executive directors on the board. NX3 is a dummy variable that takes the value 1 of a board has at least three non-executive directors of 
which at least two are independent and zero if not. DUALITY is a dummy variable that has a value if one of he posts of CEO and chairman are undertaken by a single person and zero if they are separated. CODE is a dummy variable that has the value 1 if a company has at least three non-executive directors, at least two of which are independent, and zero if not. FCF is operating cash flow minus interest, taxes and dividend divided by sales. VALUE is the market capitalisation at the time of the last published accounts divided by the market capitalisation the year before. BRDSH2 is the percentage of issued capital owned by the board deflated by total assets. SALESG is the percentage change in sales over the two years prior to being acquired. CAPEX is the percentage net capital expenditure over total assets, defined as current assets plus fixed assets. 
Table 5 Multinomial logistic regression explaining the differences between MBOs $(n=62)$ and traditional acquisitions of listed corporations $(n=258)$

\begin{tabular}{|c|c|c|c|c|}
\hline & Model 12 & Model 13 & Model 14 & Model 15 \\
\hline RUMOURS & $\begin{array}{l}0.3115 \\
(0.96)\end{array}$ & $\begin{array}{c}0.2909 \\
(0.90)\end{array}$ & $\begin{array}{l}0.2793 \\
(0.87)\end{array}$ & $\begin{array}{c}0.4374 \\
(1.32)\end{array}$ \\
\hline PIND & $\begin{array}{l}-0.0230 \\
(2.40)^{* *}\end{array}$ & & & $\begin{array}{l}-0.0222 \\
(2.34)^{* *}\end{array}$ \\
\hline $\begin{array}{c}\text { NX3 } \\
\text { DUALITY }\end{array}$ & $\begin{array}{c}0.7150 \\
(2.10)^{* *}\end{array}$ & $\begin{array}{c}-0.5726 \\
(1.85)^{*} \\
0.6736 \\
(1.99)^{* *}\end{array}$ & & $\begin{array}{l}0.6559 \\
(1.92)^{*}\end{array}$ \\
\hline CODE & & & $\begin{array}{c}-0.8996 \\
(2.94)^{* * *}\end{array}$ & \\
\hline FCF & $\begin{array}{l}0.0125 \\
(0.86)\end{array}$ & $\begin{array}{l}0.0132 \\
(0.91)\end{array}$ & $\begin{array}{l}0.0146 \\
(0.99)\end{array}$ & $\begin{array}{l}0.0098 \\
(0.66)\end{array}$ \\
\hline VALUE & $\begin{array}{c}-0.3787 \\
(1.30)\end{array}$ & $\begin{array}{c}-0.3782 \\
(1.32)\end{array}$ & $\begin{array}{c}-0.3591 \\
(1.21)\end{array}$ & $\begin{array}{c}-0.3403 \\
(1.14)\end{array}$ \\
\hline BRDSH2 & $\begin{array}{c}0.1560 \\
(1.98)^{* *}\end{array}$ & $\begin{array}{c}0.1664 \\
(2.14)^{* *}\end{array}$ & $\begin{array}{c}0.1704 \\
(2.22)^{* *}\end{array}$ & \\
\hline CAPEX & $\begin{array}{l}-0.0107 \\
(1.06)\end{array}$ & $\begin{array}{c}-0.0073 \\
(0.72)\end{array}$ & $\begin{array}{c}-0.0068 \\
(0.67)\end{array}$ & $\begin{array}{c}-0.0120 \\
(1.18)\end{array}$ \\
\hline SALESG & $\begin{array}{l}-0.0087 \\
(1.16)\end{array}$ & $\begin{array}{c}-0.0111 \\
(1.43)\end{array}$ & $\begin{array}{c}-0.0118 \\
(1.49)\end{array}$ & $\begin{array}{c}-0.0085 \\
(1.18)\end{array}$ \\
\hline Constant & $\begin{array}{c}-0.5410 \\
(1.07)\end{array}$ & $\begin{array}{c}-1.0686 \\
(2.74)^{* * *}\end{array}$ & $\begin{array}{l}-0.8046 \\
(2.24)^{* *}\end{array}$ & $\begin{array}{c}-0.8155 \\
(1.55)\end{array}$ \\
\hline Chi square & $21.51 * * *$ & $19.32 * *$ & $18.32 * *$ & $29.21 * * *$ \\
\hline
\end{tabular}

$\mathrm{t}$ values on parentheses

$* * *$ - significant at the $1 \%$ level; $* *$ - significant at the $5 \%$ level; * - significant at the $10 \%$ level.

RUMOURS is a dummy variable that takes a value of 1 if there had been press coverage of bid speculation in the period three months to fifteen months prior to the announcement of the either going private or being acquired and zero if not. PIND is the percentage of independent non-executive directors on the board. NX3 is a dummy variable that takes the value 1 of a board has at least three non-executive directors of which at least two are independent and zero if not. DUALITY is a dummy variable that has a value if one of he posts of CEO and chairman are undertaken by a single person and zero if they are separated. CODE is a dummy variable that has the value 1 if a company has at least three non-executive directors, at least two of which are independent, and zero if not. FCF is operating cash flow minus interest, taxes and dividend divided by sales. VALUE is the market capitalisation at the time of the last published accounts divided by the market capitalisation the year before. BRDSH2 is the percentage of issued capital owned by the board deflated by total assets. SALESG is the percentage change in sales over the two years prior to being acquired. CAPEX 
is the percentage net capital expenditure over total assets, defined as current assets plus fixed assets. 